\title{
Indomethacin treatment slows disease progression and enhances a Th1 response in susceptible BALB/c mice infected with Leishmania major
}

\author{
LUIZ A.R.DE FREITAS ${ }^{1}$, M.LAMINE MBOW ${ }^{2}$, MONICA ESTAY ${ }^{2}$, JULIE A.BLEYENBERG ${ }^{2}$ \& RICHARD G.TITUS ${ }^{2}$ \\ ${ }^{1}$ Laboratorio de Patologia e Biologia Celular, Centro de Pesquisas Goncalo Moniz, Fundacao Oswaldo Cruz, Salvador-Bahia, Brazil \\ ${ }^{2}$ Department of Pathology, College of Veterinary Medicine and Biomedical Sciences, Colorado State University, Fort Collins, CO 80523, USA
}

\section{SUMMARY}

Prostaglandins of the E series inhibit the development of Th1 responses. When infected with Leishmania major, $B A L B / c$ mice fail to develop a Th1 response, but instead mount a Th2 response and die of the disease. Therefore, we treated L. major-infected BALB/c mice with indomethacin, which inhibits prostaglandin production. Indomethacin lessened disease severity (parasite burden and pathology), and promoted a Th1 response, but the mice still succumbed to infection. The explanation for these observations may be two-fold: (1) the beneficial effects of indomethacin were predominantly observed later in infection (beyond two weeks), a time at which indomethacin was unable to sufficiently block the development of a Th2 response; (2) indomethacin was unable to induce a Th1 response in BALB/c mice that was of the same magnitude as the Th1 response observed in C57BL/6 mice infected with L. major.

Keywords Leishmania major, leishmaniasis, prostaglandins, cytokines, nitric oxide

Correspondence: Richard G.Titus

Accepted for publication: 22 September 1998

\section{INTRODUCTION}

Work in several laboratories has revealed that prostaglandin (PGE, in particular, $\mathrm{PGE}_{2}$ and $\mathrm{PGE}_{1}$ ) inhibits Th1 responses and the production of interferon (IFN)- $\gamma$ and interleukin (IL)-2 by the cells (Phipps et al. 1991). Among in vivo models that generate a chronic immune/inflammatory response whose outcome is dictated by the selective activation of either Th1 or Th2 cells, infection of mice with $L$. major is a well-studied example (reviewed in Bogdan, Gessner \& Rollinghoff 1993, Liew \& O’Donnell 1993, Reed \& Scott 1993, Titus et al. 1994, Reiner \& Locksley 1995). Following infection with L. major, resistant strains of mice (e.g., C57BL/6, CBA) produce IL-2, IFN- $\gamma$ and nitric oxide $(\mathrm{NO})$, whereas susceptible mice $(\mathrm{BALB} / \mathrm{c})$ produce IL-4, but small amounts of IL-2, IFN- $\gamma$, and NO. Interferon$\gamma$ is an important mediator of resistance since it activates macrophages (MØs) to destroy L. major by inducing the production of factors such as NO. On the other hand, IL-4 can block the activating effects of IFN- $\gamma$.

It is possible that production of PGE contributes to the predominance of a Th2 response in susceptible BALB/c mice infected with L. major. Therefore, groups of four female BALB/c mice each (National Cancer Institute, Frederick, MD, USA or Jackson Laboratories, Bar Harbor, ME, USA) were placed on treatment with the PGE blocker, indomethacin (20 $\mu \mathrm{g}$ indomethacin (I 7378 Sigma, St Louis, $\mathrm{MO}, \mathrm{USA}) / \mathrm{ml}$ and $0.4 \%$ ethanol added to the drinking water of experimental mice, and ethanol added to the drinking water of controls; changed twice weekly, Farrell \& Kirkpatrick 1987). Twenty-four h later, the mice were infected with $5 \times 10^{6}$ L. major (isolate LV39) subcutaneously in a hind footpad.

We first determined whether indomethacin blocked $\mathrm{PGE}_{2}$ production in treated mice. Popliteal and inguinal lymph 
node cells that drained the lesions were removed at varying times after infection and single cell suspensions were prepared. Lymph node cells were cultured at $5 \times 10^{6}$ cells/ $\mathrm{ml}$ in culture medium consisting of Dulbecco's modified Eagle's medium (Titus et al. 1991) supplemented with 0.5\% normal mouse serum. One $\mathrm{ml}$ aliquots of the cell suspension were plated into 24-well tissue culture plates (Costar 3524, Cambridge, MA, USA). L. major $\left(10^{6} / \mathrm{ml}\right)$ was added; control cultures contained no parasites. In some cases, lymph node cells were also cultured in the presence of indomethacin $(2 \mu \mathrm{g} / \mathrm{ml}$, Farrell et al. 1987) to determine whether the drug would inhibit the production of $\mathrm{PGE}_{2}$ still further by the lymph node cells. Supernatants of the cultures were collected at 48 hours and assayed for $\mathrm{PGE}_{2}$ by published methods (Urioste et al. 1994). $\mathrm{PGE}_{2}$ was produced at all timepoints tested. For example, at five weeks of infection, ethanol-treated BALB/c mice produced $3633 \mathrm{pg}$ $\mathrm{PGE}_{2} / \mathrm{ml}$ and indomethacin-treated mice produced $1086 \mathrm{pg} /$ $\mathrm{ml}$. This was true whether the lymph node cells were restimulated or not with $L$. major. Finally, production of $\mathrm{PGE}_{2}$ was reduced still further by including indomethacin in the lymph node cell cultures $(647 \mathrm{pg} / \mathrm{ml})$. Therefore, our indomethacin treatment regimen reduced $\mathrm{PGE}_{2}$ production, and this was a stable phenotype in vitro.

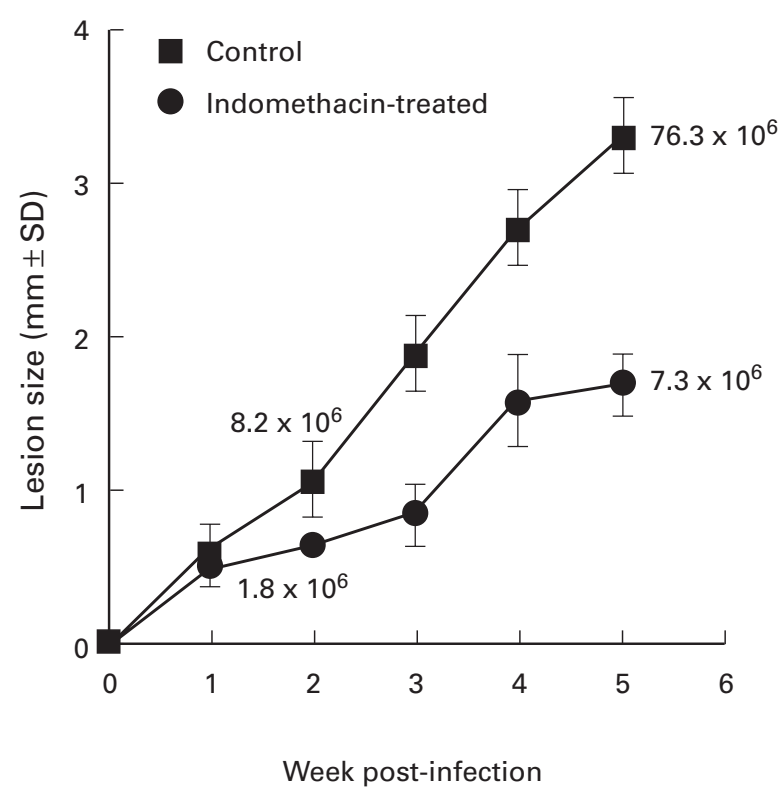

Figure 1 Indomethacin treatment slows lesion development and the outgrowth of parasites in BALB/c mice infected with Leishmania major. There was a significant difference in the size of lesions in the two groups from week 2 through 5 of infection $0.0000004<P<0.003$, unpaired $t$-test). The numbers next to the symbols in the figure are the parasite burdens present in the lesions at weeks 2 and 5 of infection. Data are representative of five independent experiments. All experiments were terminated at five weeks of infection due to lesion ulceration and necrosis, especially in control groups.
Next, we monitored lesion size and lesion parasite burden (techniques in Titus et al. 1985) in indomethacin treated mice. Indomethacin treatment significantly slowed the development of lesions and the outgrowth of parasites in the lesions (Figure 1).

Since indomethacin treatment had a therapeutic effect (Figure 1), we characterized the immune response to $L$. major in treated mice. Draining lymph node cells were stimulated as described above and the $48 \mathrm{~h}$ supernatants were assayed for the levels of IFN- $\gamma$ by ELISA (Shankar \& Titus 1995). In addition, the level of $\mathrm{NO}_{2}$ (which reflects $\mathrm{NO}$ production) was measured using published techniques (Urioste et al. 1994). Since IL-4 could not be consistently detected in these supernatants, we stimulated, rested and restimulated lymph node cells as described (Shankar et al. 1995). Supernatants were collected from the restimulation cultures at $48 \mathrm{~h}$ and assayed for IL-4 by ELISA.

Indomethacin treatment had no significant effect on the production of IFN- $\gamma$, IL-4 or NO at two weeks of infection (data not shown), but the production of each of these mediators was significantly affected by five weeks of infection (Table 1). The effect of indomethacin was to skew the immune response to L. major towards a Th1 response, but these effects of the drug were insufficient to allow the mice to heal their infections. It should also be noted that we attempted to augment the protective effects of indomethacin by treating with the drug for $72 \mathrm{~h}$ before injecting $L$. major, and by administering higher doses. Neither approach enhanced the effect of indomethacin. It is important to mention that even a three-fold increase in the dose of indomethacin resulted in some death in the treated mice.

To confirm and extend the cytokine results of Table 1, we harvested the popliteal and inguinal lymph nodes draining the lesion, isolated total RNA and determined the levels of expression of IL-4, IFN- $\gamma$ and inducible nitric oxide synthase (iNOS) mRNA using a competitive polymerase chain reaction (PCR) assay described elsewhere (Mbow et al.

Table 1 Production of cytokines and nitric oxide at five weeks of infection*

\begin{tabular}{lccc}
\hline & \multicolumn{3}{c}{ Level of factor produced } \\
\cline { 2 - 4 } Group & $\begin{array}{c}\mathrm{IFN}-\gamma \\
\text { (units/ml } \pm \mathrm{SD})\end{array}$ & $\begin{array}{c}\mathrm{NO}_{2} \\
(\mu \mathrm{M} \pm \mathrm{SD})\end{array}$ & $\begin{array}{c}\mathrm{IL}-4 \\
(\mathrm{ng} / \mathrm{ml} \pm \mathrm{SD})\end{array}$ \\
\hline Control & $16 \cdot 3 \pm 0$ & $1 \cdot 3 \pm 0$ & $86 \cdot 1 \pm 3 \cdot 3$ \\
Indomethacin & $160 \cdot 0 \pm 16$ & $12 \cdot 0 \pm 1 \cdot 1$ & $15 \cdot 4 \pm 0 \cdot 7$ \\
\hline
\end{tabular}

* Data are representative of three independent experiments. The levels of the factors produced by the two groups were significantly different $(0.0001<P<0.005$, unpaired $t$-test $)$. 
1998). For these experiments we also analysed the expression of the same mRNAs in resistant C57BL/6 mice infected with $L$. major and treated as BALB/c control mice were with ethanol in their drinking water. Including this $\mathrm{C} 57 \mathrm{BL} / 6$ control group allowed us to determine whether indomethacin promoted a Th1 response to L. major infection in BALB/c mice that was as intense as the Th1 response present in resistant C57BL/6 mice infected with the parasite. Consistent with the results of Table 1, at five weeks of infection indomethacin treated $\mathrm{BALB} / \mathrm{c}$ mice were expressing approximately 4-fold more iNOS mRNA than ethanol treated control mice (Figure 2). However the level of expression of iNOS mRNA in indomethacin treated $\mathrm{BALB} / \mathrm{c}$ mice was still four-fold less than the expression of iNOS mRNA in resistant C57BL/6 mice infected with L. major (Figure 2). Interestingly, there was little difference in the expression of IFN- $\gamma$ mRNA at five weeks of infection in BALB/c mice treated or not with indomethacin (Figure 2). Rather, we found that differences in IFN- $\gamma$ mRNA expression were seen at two weeks of infection when indomethacin treated BALB/c mice produced four-fold less IFN- $\gamma$ mRNA than C57BL/6 mice but four-fold more IFN- $\gamma$ mRNA than ethanol treated control BALB/c mice. This suggests that the production of IFN- $\gamma$ mRNA and IFN- $\gamma$ secreted protein follow different kinetics in mice infected with $L$. major. Namely, when differences in IFN- $\gamma$ mRNA expression are detected (two weeks of infection), no differences in the levels of secreted protein were found; however, by five

\section{BALB/c BALB/c C57BL/6 \\ $L$ Control Indomethacin Control}

iNOS

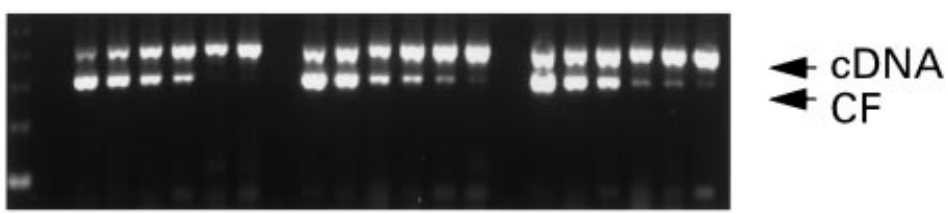

Figure 2 Effect of indomethacin treatment on cytokine gene expression in mice infected with Leishmania major. Total RNA was isolated from groups of three mice five weeks after injection of $L$. major. Competitive reverse transcription-polymerase chain reaction (RTPCR) was used to monitor the expression of a variety of cytokine/monokine genes as previously described (Mbow et al. 1998). PCR products were separated by electrophoresis in $1.6 \%$ agarose gel containing ethidium bromide. The bottom picture represents cDNA samples from indomethacin-treated BALB/c mice $(4,5$, $6)$ and control BALB/c $(1,2,3)$ and C57BL/6 mice $(8,9,10)$ normalized to equal $\beta$-actin concentrations using the same dilutions of the $\beta$-actin competitor. First strand cDNA synthesis in the absence of the reverse transcriptase MML-V was carried out as a control for potential genomic DNA contamination $(3,6$, 10). Point of equivalent intensity of ethidium bromide-stained bands between cDNA and competitive fragment was determined by scanning the gels using a digital imaging system. Serial four-fold dilutions of the competitor plasmid were added in the PCR reactions: iNOS: $0.0191 \mathrm{pg}$ to $1.86 \times 10^{-5} \mathrm{pg}$; IFN- $\gamma$ : $0 \cdot 103 \mathrm{pg}$ to $1 \times 10^{-4} \mathrm{pg}$; IL-4: $0.0956 \mathrm{pg} \quad \beta$-actin to $9.3 \times 10^{-5}$ pg. L, 123 bp DNA ladder; $\mathrm{CF}$, IFN- $\gamma$
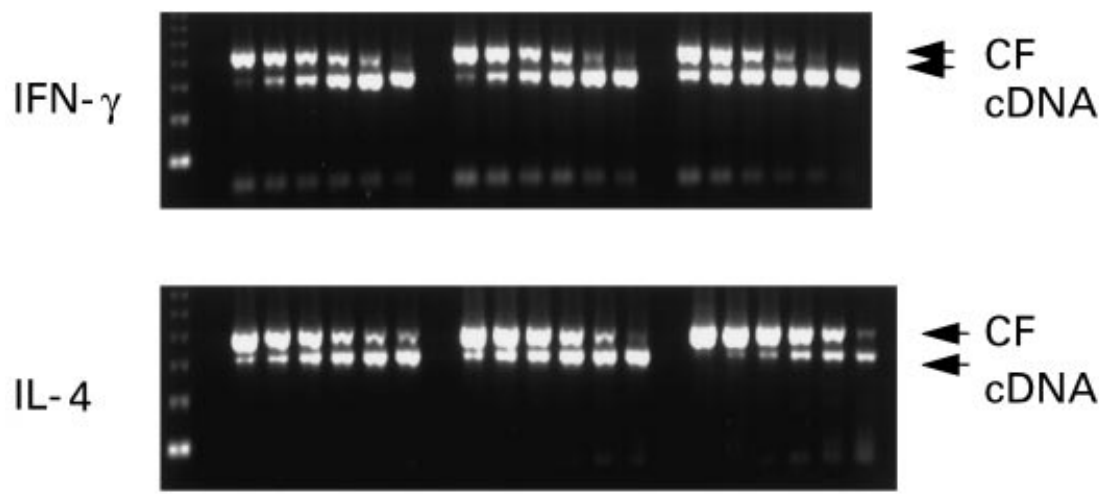
competitive fragment.

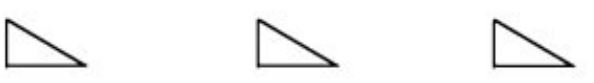

Competitive mimic titration

L $\quad 123 \quad 456 \quad 8910$

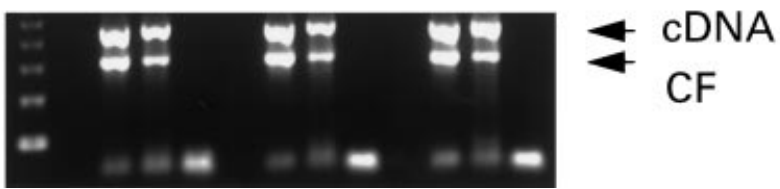


weeks of infection the levels of secreted protein were different (Table 1). Finally, we did not see a difference in the levels of expression of IL-4 mRNA in BALB/c mice treated or not with indomethacin (Figure 2); both BALB/c mouse groups produced substantially more IL-4 mRNA than did C57BL/6 mice (Figure 2). Thus, the effects of indomethacin on IL-4 production may be minimal.

Previous studies have shown that lesion histological patterns reflect the host immune status in leishmaniasis (Barral-Netto, Freitas \& Andrade 1987, Pompeu et al. 1992, Almeida et al. 1996). Therefore, to corroborate the results obtained above, we examined histological changes in control and indomethacin treated mice at five weeks of infection. Both groups showed extensive skin ulceration and the subcutaneous tissue was infiltrated by many heavily parasitized MØ. Within these areas, foci of suppurative necrosis were observed. These aspects are similar to those described in human diffuse cutaneous leishmaniasis and in susceptible mice infected with different species of Leishmania (Ridley \& Ridley 1983, Andrade et al. 1984). However, some clear differences between the groups were also noted. Necrotic areas were fewer and smaller in the indomethacintreated mice. In addition, in indomethacin-treated mice, areas of mixed cell inflammatory reactions and areas of granulomatous reaction were also seen. Only few parasitized $\mathrm{M} \varnothing$ could be found among these cells. In addition, fibrosis occurred around these areas and focal fibrinoid necrosis was also observed. This type of tissue reaction correlates with resistance in leishmaniasis (Perez et al. 1979, Ridley et al. 1983, Andrade et al. 1984). Therefore, indomethacin treatment induced partial resistance and this correlated with a mixed histopathological pattern in the lesion with features related to susceptibility co-existing with features related to resistance.

The present study confirms and extends the work of Farrell et al. (1987). These authors found that indomethacin treatment slowed lesion development in L. major-infected $\mathrm{BALB} / \mathrm{c}$ mice. Moreover, these authors also found that the beneficial effects of indomethacin were seen predominantly after the first few weeks of infection.

Although indomethacin skewed the L. major-infected $\mathrm{BALB} / \mathrm{c}$ mouse towards a Th1 response to the parasite, lesions still progressed on treated mice and the animals eventually succumbed to infection. The reason(s) why indomethacin was unable to reverse the outcome of infection is unknown. However, several possibilities can be entertained. The protective effects of indomethacin did not manifest themselves until late in infection (Figure 1). Treatments that profoundly affect the outcome of infection with L. major [e.g., anti-IL-4 (Sadick et al. 1990) or antiIFN- $\gamma$ (Belosevic et al. 1989)] have their effects within the first week of infection with L. major. Therefore, it is possible that by the time indomethacin exerted its protective effect, the Th2 response of the BALB/c mouse could not be blocked sufficiently to allow the mouse to heal. Moreover, once infected with Leishmania, it is difficult to activate MØs to destroy the parasite because the infected cells produce a factor that blocks activation by IFN- $\gamma$ (Engelhorn et al. 1990). In addition, transforming growth factor- $\beta$ is produced by MØs following infection with Leishmania (Barral et al. 1993), and it has been proposed that Leishmania can escape destruction by the host through inducing the production of transforming growth factor- $\beta$ (Barral-Netto et al. 1992). An alternative explanation for why indomethacin was unable to induce cure in BALB/c mice infected with L. major is that although the drug skewed the response of the BALB/c mice toward Th1, the intensity of this response never was equivalent to the Th1 response of a resistant C57BL/6 mice infected with the parasite (Figure 2).

In conclusion, treating with indomethacin lessened disease severity (parasite burden and pathology), and promoted a Th1 response in L. major-infected BALB/c mice, but the animals still succumbed to infection. Thus, it is becoming clear that several factors that can be produced by, or can affect the functions of, MØs and other phagocytic cells (the host cells for $L$. major) may influence $L$. major infection. These factors include $\mathrm{PGE}_{2}$ (this report, Farrell et al. 1987), IL-1 (Theodos et al. 1994), IL-8 and monocyte chemoattractant and activating factor (Badolato et al. 1996), IL-10 (Heinzel et al. 1991), IL-12 (Heinzel et al. 1993, Sypek et al. 1993), TNF- $\alpha$ (Titus et al. 1989, Vieira et al. 1996) granulocyte MØ-colony stimulating factor (Doherty $\&$ Coffman 1993), transforming growth factor- $\beta$ (Stenger $e t$ al. 1994) and IFN- $\alpha / \beta$ (Shankar et al. 1996).

\section{ACKNOWLEDGEMENT}

This work was supported by grants from the Brazilian Research Council (LARF; CNPq 260182/992-3 NV), and NIH (AI 29955).

\section{REFERENCES}

Almeida R.P., Barral-Netto M., Ribeiro de Jesus A., Freitas L.A.R., Carvalho, E.M. \& Barral, A. (1996) Biological behavior of Leishmania amazonensis isolated from humans with cutaneous, mucosal or visceral leishmaniasis in BALB/c mice. American Journal of Tropical Medicine and Hygiene 54, 178-184

Andrade Z.A., Reed S.G., Roters, S. \& Sadigursky, M. (1984) Immunopathology of experimental cutaneous leishmaniasis. American Journal of Pathology 114, 137-148

Badolato R., Sacks D.L., Savoia, D. \& Musso, T. (1996) Leishmania major: infection of human monocytes induces expression of IL-8 and MCAF. Experimental Parasitology 82, 21-26

Barral A., Barral-Netto M., Yong E.C., Brownell C.E., Twardzik, D.R. 
\& Reed, S.G. (1993) Transforming growth factor $\beta$ as a virulence mechanism for Leishmania braziliensis. Proceedings of the National Academy of Sciences, USA 90, 3442-3426

Barral-Netto M., Barral A., Brownell C.E., Skeiky Y.A.W., Ellingsworth L.R., Twardzik, D.R. \& Reed, S.G. (1992) Transforming growth factor- $\beta$ in leishmanial infection: a parasite escape mechanism. Science 257, 545-548

Barral-Netto M., Freitas, L.A.R. \& Andrade, Z.A. (1987) Histopathologic changes induced by vaccination in experimental cutaneous leishmaniasis of BALB/c mice. American Journal of Pathology 127, 271-278

Belosevic M., Finbloom D.S., van der Meide P., Slayter, M.V. \& Nacy, C.A. (1989) Administration of monoclonal anti IFN- $\gamma$ antibodies in vivo abrogates natural resistance of $\mathrm{C} 3 \mathrm{H} / \mathrm{HeN}$ mice to infection with Leishmania major. Journal of Immunology 143, 266-274

Bogdan C., Gessner, A. \& Rollinghoff, M. (1993) Cytokines in leishmanaisis: a complex network of stimulatory and inhibitory interactions. Immunobiology 189, 356-396

Doherty, T.M. \& Coffman, R.L. (1993) Leishmania antigens presented by GM-CSF-derived macrophages protect susceptible mice against challenge with Leishmania major. Journal of Immunology 150, 5476-5483

Engelhorn S., Bruckner A., Remold, H.G. (1990) A soluble factor produced by inoculation of human monocytes with Leishmania donovani promastigotes suppresses IFN- $\gamma$-dependent monocyte activation. Journal of Immunology 145, 2662-2668

Farrell, J.P. \& Kirkpatrick, C.E. (1987) Experimental cutaneous leishmaniasis. II. A possible role for prostaglandins in exacerbation of disease in Leishmania major-infected BALB/c mice. Journal of Immunology 138, 902-907

Heinzel F.P., Sadick M.D., Mutha, S.S. \& Locksley, R.M. (1991) Production of interferon $\gamma$, interleukin 2, interleukin 4 and interleukin 10 by $\mathrm{CD}^{+}$lymphocytes in vivo during healing and progressive murine leishmaniasis. Proceedings of the National Academy of Sciences, USA 88, 7011-7015

Heinzel F.P., Schoenhaut D.S., Rerko R.M., Rosser, L.E. \& Gately, M.K. (1993) Recombinant interleukin 12 cures mice infected with Leishmania major. Journal of Experimental Medicine 177, 1505-1509

Liew, F.Y. \& O'Donnell, C.A. (1993) Immunology of leishmaniasis. Advances in Parasitology 32, 161-259

Mbow M.L., Bleyenberg J.A., Hall, L.R. \& Titus, R.G. (1998) Phlebotomus papatasi sand fly salivary gland lysate downregulates a Th1, but upregulates a Th2, response in mice infected with Leishmania major. Journal of Immunology 161, 5571-5577

Perez H., Labrador, F. \& Torrealba, J.W. (1979) Variation in the response of five strains of mice to Leishmania mexicana. International Journal of Parasitology 9, 27-32

Phipps R.P., Stein, S.H. \& Roper, R.L. (1991) A new view of prostaglandin $\mathrm{E}$ regulation of the immune response. Immunology Today 12, 349-352

Pompeu M.M., Freitas L.A.R., Santos M.L.V., Barral, A. \& BarralNetto, M. (1992) Leishmania amazonensis infection: a comparison of in vivo leishmanicidal mechanism between immunized and naive infected BALB/c mice. Experimental Parasitology 74, 169-176
Reed, S.G. \& Scott, P. (1993) T-cell and cytokine responses in leishmaniasis. Current Opinion in Immunology 5, 524-531

Reiner, S.L. \& Locksley, R.M. (1995) The regulation of immunity to Leishmania major. Annual Reviews in Immunology 13, 151-177

Ridley, D.S. \& Ridley, M.J. (1983) The evolution of the lesion in cutaneous leishmaniasis. Journal of Pathology 141, 83-96

Sadick M.D., Heinzel F.D., Holaday B.J., Pu R.T., Dawkins, R.S. \& Locksley, R.M. (1990) Cure of murine cutaneous leishmaniasis with anti-interleukin 4 monoclonal antibody. Evidence for a $\mathrm{T}$ celldependent, interferon $\gamma$-independent mechanism. Journal of Experimental Medicine 171, 115-127

Shankar, A.H. \& Titus, R.G. (1995) T cell and non-T cell compartments can independently determine resistance to Leishmania major. Journal of Experimental Medicine 181, 845-855

Shankar A.H., Morin, P. \& Titus, R.G. (1996) Leishmania major: differential resistance to infection in C57BL/6 (high interferon- $\alpha$ / $\beta$ ) and congenic B6.C-H28 (low interferon- $\alpha / \beta$ ) mice. Experimental Parasitology 84, 136-143

Stenger S., Thuring H., Rollinghoff, M. \& Bogdan, C. (1994) Tissue expression of inducible nitric oxide is closely associated with resistance to Leishmania major. Journal of Experimental Medicine 180, 783-793

Sypek J.P., Chung C.L., Mayor S.E., Subramanyam J.M., Goldman S.J., Sieburth D.S., Wolf, S.F. \& Schaub, R.G. (1993) Resolution of cutaneous leishmaniasis: Interleukin 12 initiates a protective $\mathrm{T}$ helper type 1 immune response. Journal of Experimental Medicine 177, 1797-1802

Theodos C.M., Shankar A., Glasebrook A.L., Roeder, W.D. \& Titus, R.G. (1994) The effect of treating with anti-interleukin-1 receptor antibody on the course of experimental murine cutaneous leishmaniasis. Parasite Immunology 16, 571-577

Titus R.G., Marchand M., Boom, T. \& Louis, J.A. (1985) A limiting dilution assay for quantifying Leishmania major in tissues of infected mice. Parasite Immunology 7, 545-555

Titus R.G., Muller I., Kimsey P., Cerny A., Behin R., Zinkernagel, R.M. \& Louis, J.A. (1991) Exacerbation of experimental murine cutaneous leishmaniasis with $\mathrm{CD}^{+}{ }^{+}$Leishmania major-specific $\mathrm{T}$ cell lines or clones which secrete interferon-gamma and mediate parasite-specific delayed-type hypersensitivity. European Journal of Immunology 21, 559-567

Titus R.G., Sherry, B. \& Cerami, A. (1989) Tumor necrosis factor plays a protective role in experimental murine cutaneous leishmaniasis. Journal of Experimental Medicine 170, 2097-2104

Titus R.G., Theodos C.M., Shankar, A. \& Hall, L.R. (1994) Interactions between Leishmania major and macrophages. Immunology Series $\mathbf{6 0}$, 437-459

Urioste S., Hall L.R., Telford S.R., Jr. \& Titus, R.G. (1994) Saliva of the Lyme disease vector, Ixodes dammini, blocks cell activation by a non-prostaglandin $\mathrm{E}_{2}$-dependent mechanism. Journal of Experimental Medicine 180, 1077-1086

Vieira L.Q., Goldscmidt M., Nashleanas M., Pfeiffer K., Mak, T. \& Scott, P. (1996) Mice lacking the TNF receptor p55 fail to resolve lesions caused by infection with Leishmania major, but control parasite replication. Journal of Immunology 157, 827-835 